Journal of Clinical Investigation

Vol. 41, No. 11, 1962

\title{
IMMUNOGLOBULIN LEVELS FROM THE NEWBORN PERIOD TO ADULTHOOD AND IN IMMUNOGLOBULIN DEFICIENCY STATES *
}

\author{
By CLARK D. WEST, RICHARD HONG, $†$ AND NANCY H. HOLLAND
}

(From the Children's Hospital Research Foundation and the Department of Pediatrics, Unii'ersity of Cincinnati College of Medicine, Cincinnati, Ohio)

(Submitted for publication March 29, 1962 ; accepted July 26, 1962)

Beta-2A globulin and the $7 \mathrm{~S}$ and $19 \mathrm{~S}$ gamma globulins are the major proteins of the serum derived from the immune system. Collectively they nave been termed the immunoglobulins. The 19S gamma globulin. also known as the gamma-1 macroglobulin, the $\beta_{2}$ macroglobulin or $\beta_{2 \mathrm{M}}$, has been the subject of intensive study in recent years. The rheumatoid factor as well as a variety of antibodies fall into this protein group, and abnormally high levels are found in Waldenstroem's macroglobulinemia. Less is known about $\beta_{2 \mathrm{~A}}$ globulin (gamma 1-A). It is like gamma globulin in that it has a sedimentation constant of $7 \mathrm{~S}$, but contains more carbohydrate (1). Recent observations imply that it is the carrier of the reaginic activity of the serum (2). All of immunoglobulins are easily detectable in normal adult serum by immunoelectrophoretic analysis. $\beta_{2 \mathrm{~A}}$ and $\beta_{2 \mathrm{M}}$ are absent in cord serum, and in agammaglobulinemia all three immunoglobulins are absent or in greatly reduced concentrations. Other antibody deficiency states have been described in which only one or two immunoglobulins are in low concentration (3-6).

The present paper reports the levels of the immunoglobulins in cord serum and in the serum of infants, children, and adults as determined by a method based on a combination of immunoelectrophoretic analysis and the quantitative precipitin reaction (7). The data reveal a variable rate of maturation of the synthetic mechanisms for these proteins that is not apparent from semi-quantitative estimates based on simple immunoelectrophoretic analysis of serum. Also reported are the

\footnotetext{
* Supported in part by Grant E-3429 from the National Institute of Allergy and Infectious Diseases, U. S. Public Health Service.

† This work was done on a postdoctoral research fellowship at the National Institute of Allergy and Infectious Diseases, U. S. Public Health Service.
}

serum levels of the immunoglobulins in various immunoglobulin and antibody deficiency states, including agammaglobulinemia, hypogammaglobulinemia, agammaglobulinemia with $\beta_{2}$ macroglobulinemia, isolated $\beta_{2 \mathrm{~A}}$ deficiency, various transient hypoimmunoglobulinemias, and the Aldrich syndrome.

The data bring out a number of points concerning interrelationships among the immunoglobulins. In all the deficiency states, the most frequently affected immunoglobulin is $\beta_{2 A}$. This protein was usually low or absent in conditions in which $\beta_{2 \mathrm{M}}$ and gamma globulin were low. Beta-2A does not appear, however, to have antibody activity of clinical importance, since isolated $\beta_{2 A}$ deficiency seen in a number of subjects is not associated with an antibody deficiency syndrome. Isolated $\beta_{2 M}$ deficiency was not seen. In certain of the deficiency states the immunoglobulin patterns correspond closely to those that would obtain with arrest of development at various stages in the immunoglobin maturation sequence. An unexpected observation was an unusually high level of $\beta_{2 A}$ in Aldrich's syndrome (8), a hereditary disease characterized by absence of isohemagglutinins and predisposition to infection.

\section{EXPERIMENTAL METHODS}

For studies of the maturation of the immunoglobulins, determinations of $\beta_{2 \mathrm{~A}}$ and $\beta_{2 \mathrm{M}}$ were performed on 198 specimens of serum from 152 normal individuals. Of these, 42 specimens were from 29 adults who were laboratory workers and physicians and 58 specimens were from 25 normal infants under 4 months of age, most of whom were awaiting adoption in an infant home. The remainder were single specimens from older infants and children, who were attending an outpatient clinic, participating in vaccine evaluation programs, or living in an orphans' home. The medical background of these children was evaluated before including the results in the study. Measurements were also done on 24 specimens of cord serum. The serum specimens were stored at $-10^{\circ} \mathrm{C}$ 
until used. It has been found that storage at this temperature for over a year does not affect the determination of immunoglobulin levels.

In the investigation of immunoglobulin deficiency states, 30 patients were studied. Of these, ten had agammaglobulinemia, four had a transient, partial hypoimmunoglobulinemia, 13 had isolated $\beta_{2 \mathrm{~A}}$ deficiency, and two had Aldrich's syndrome.

Mcthod for determination of $\beta_{z A}$ and $\beta_{z \mathbf{z}}$ globulins. The measurement of $\beta_{2 \mathrm{~A}}$ and $\beta_{2 \mathrm{M}}$ globulins and the arbitrary units used to express their concentrations have been described in a previous publication (7). Briefly, the method consists of determining the volume of serum that results in nearly complete consumption of the antibody present in a given volume of standardized antiserum. Immunoelectrophoretic analysis is used to detect residual antibody in the supernatant fluid. The units used in expressing concentration are arbitrary. Units for $\beta_{2 \mathrm{~S}}$ and $\beta_{2 \mathrm{M}}$ are not related and, in the absence of a pure preparation of these proteins, factors for correcting them to milligrams are not as yet available. The order of magnitude of the milligram equivalents of a unit can be calculated, however. If we assume that the level of $\beta_{2}$ macroglobulin in normal serum is $75 \mathrm{mg}$ per $100 \mathrm{ml}$, a unit of $\beta_{2 \mathrm{M}}$ may be estimated as representing about $60 \mu \mathrm{g}$ of protein. The error in this estimate could be, however, as great as 40 per cent. Quantification of plasma fractions greatly enriched in $\beta_{2 \mathrm{~A}}$ has, in this laboratory, indicated that a unit of this protein is equivalent to something less than $42 \mu \mathrm{g}$ of protein.

The antiserums used were produced in goats. Although it was stated previously (7) that with goat antiserum cross-reactions between $\beta_{2 \mathrm{~A}}, \beta_{2 \mathrm{M}}$, and gamma globulins do not occur, further study has indicated this to be incorrect. In addition to specific determinant groups, there are also groupings on $\beta_{2 M}$ (9-11), and presumably also on $\beta_{2 \mathrm{~A}}(1)$, which are common to $7 \mathrm{~S}$ gamma globulin. When goat antiserum directed only against $7 \mathrm{~S}$ gamma globulin is added to serum, $\beta_{2 A}$ and $\beta_{2 M}$ as well as gamma globulin will precipitate (12). In the quantification method as used in these studies, however, antibodies specific for all three immunoglobulins are present in the standardized antiserum. In this situation, the reaction of $7 \mathrm{~S}$ antibody with $\beta_{2 A}$ does not appear to reduce the reaction of $\beta_{2 A}$ with its specific antibody. Thus, $\beta_{2 A}$ will consume the same amount of specific antibody whether or not anti-7S is present (7.). In the case of $\beta_{2 m}$, the presence of anti-7S appears to interfere to a small extent with its reaction with specific antibody. The previous study (7) showed that the presence of antibody to $7 \mathrm{~S}$ in the mixture produces a positive error of about 8 per cent in the determination of $\beta_{2 \mathrm{M}}$.

Extension of the method. The range of the method was extended in the present study to measure more precisely serum specimens with low concentrations of $\beta_{2 \mathrm{~A}}$ and $\beta_{2 \mathrm{M}}$. In the original method (7) a maximum of $0.1 \mathrm{ml}$ of serum could be added to $0.2 \mathrm{ml}$ of the antisera, giving a maximum sensitivity with antiserum, as routinely standardized, of $2 \mathrm{U}$ per $\mathrm{ml}$. For the present study, the schedule of serum additions was extended for specimens containing low concentrations of $\beta_{2 \mathrm{~A}}$ and $\beta_{2 \mathrm{M}}$ by reducing the antiserum volume to $0.1 \mathrm{ml}$ and adding a maximum of $0.2 \mathrm{ml}$ of serum. In this way the sensitivity of the procedure was increased to $0.5 \mathrm{U}$ per $\mathrm{ml}$. Since the end-point depends on the detection of a very low but finite concentration of antibody in the supernatant, the twofold dilution of antiserum occasioned by this extended schedule could conceivably introduce an error. However, when levels of $\beta_{2 \mathrm{~A}}$ and $\beta_{2 \mathrm{M}}$ determined by the usual schedule were compared with those expected in the same serum appropriately diluted and determined by the extended schedule, the error was found to be negligible. Presumably, the concentration of antibody in the end-point supernatant fluid is so low that the twofold dilution of the antiserum has little effect on it as compared to the effect of the next increment of serum addition.

Method for determination of gamma globulin. Gamma globulin was determined in most cases by an adaptation of the method for $\beta_{2 \mathrm{~A}}$ and $\beta_{2 \mathrm{M}}$ globulins. The antiserum used was standardized with a preparation of pure gamma globulin obtained by column chromatography. Details of the method as adapted for gamma globulin will be described in a later communication (13). In a few cases, gamma globulin was determined by paper electrophoresis with the usual equipment for scanning.

\section{RESULTS}

Levels of $\beta_{2 A}$ and $\beta_{2 M}$ in adult serums. Levels of $\beta_{2 \mathrm{~A}}$ and $\beta_{2 \mathrm{M}}$ in adult serums showed wide variation. The range of concentration in 27 adults was 12 to 29 with an average of $18.6 \mathrm{U}$ per $\mathrm{ml}$. The range for $\beta_{2 \mathrm{M}}$ was 5 to 20 with an average of $12 \mathrm{U}$ per $\mathrm{ml}$. The values for $\beta_{2 \mathrm{~A}}$ in females tended to be slightly lower than in males (average female level, 16.9; average male level, 20.8); values for $\beta_{2 \mathrm{M}}$ tended to be slightly higher (13.1, females; 10.6, males). For neither protein was the difference between the sexes statistically significant $(\mathrm{p}=0.05-0.10)$.

In view of the wide variation in levels of these proteins among individuals, it seemed interesting to determine the stability of the levels in a given individual. Therefore, a second specimen of serum was obtained from 15 of the normal adults 8 months after the first specimen. It was found that the levels are remarkably constant with time, especially in the case of $\beta_{2 \mathrm{~A}}$ globulin. With this protein the levels differed less than 10 per cent in 13 of the 15 subjects, and in 9 subjects the agreement was within 4 per cent. In the case of $\beta_{2 \text { M }}$ globulin, the stability of the levels was not so great; only half the subjects had levels differing less than 10 per cent. 
Levels of $\beta_{2 A}$ and $\beta_{2 M}$ in cord serum. Levels of $\beta_{2 \mathrm{~A}}$ in twenty-four specimens of cord serum were found to be uniformly less than $0.5 \mathrm{U}$ per $\mathrm{ml}$. It is probable that $\beta_{2 \mathrm{~A}}$ is completely absent from cord serum, since in previous studies (7), with a more sensitive method, no $\beta_{2 A}$ could be demonstrated. In 15 (or 71 per cent) of the 21 specimens of cord serum analyzed for $\beta_{2 \mathrm{M}}$, the level was above $0.5 \mathrm{U}$ per $\mathrm{ml}$. The highest value was $1.75 \mathrm{U}$ per $\mathrm{ml}$. Thus the statement that levels of $\beta_{2 M}$ in cord serum are one-tenth of the levels found in adult serum is approximately correct (14); in some serums, however, the level may be considerably less than this.

Levels of $\beta_{2 A}$ and $\beta_{2 M}$ in infancy and childhood. In Figure 1 the scatter of the values for $\beta_{2 A}$ and $\beta_{2 \mathrm{M}}$ in the serums of 25 normal infants during the first four months of life is shown. The values represent determinations on 58 serum specimens taken over this time and are plotted as percentages of the mean adult values (18.6 and $12 \mathrm{U}$ per $\mathrm{ml}$ for $\beta_{2 A}$ and $\beta_{2 M}$, respectively). It is readily apparent that the levels of $\beta_{2 \mathrm{M}}$ approach those of the

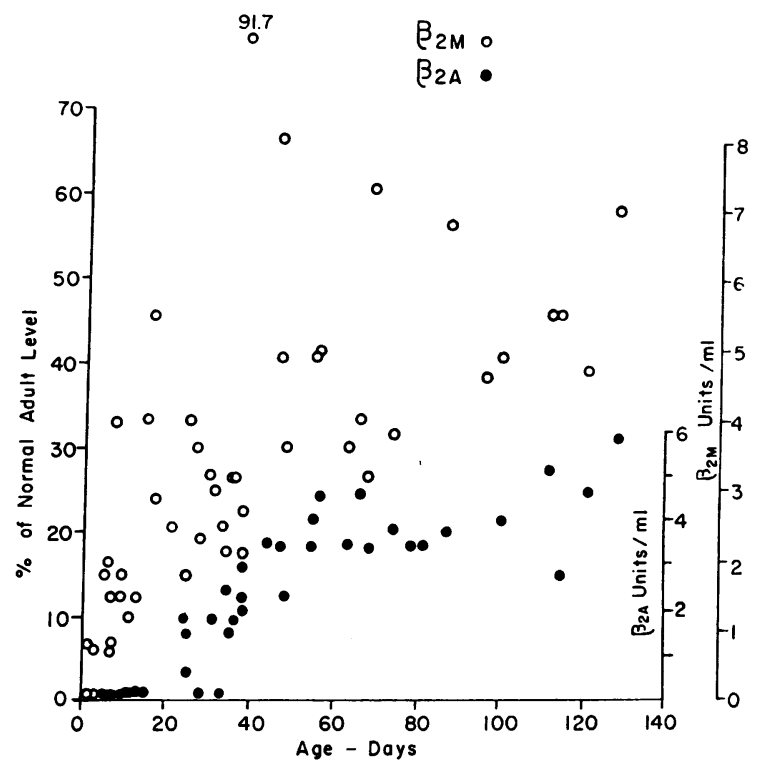

Fig. 1. Serum LeVels of $\beta_{2 A}$ AND $\beta_{2 M}$ EXPRESSEd AS PER CENT OF NORMAL ADULT LEVEl (LEFT SCALE) AND U PER ML (RIGHT SCALE) IN INFANTS IN THE FIRST 4 MONTHS OF LIFE. Points close to abscissa at lower left represent specimens with levels of $<0.5 \mathrm{U}$ per $\mathrm{ml}$.

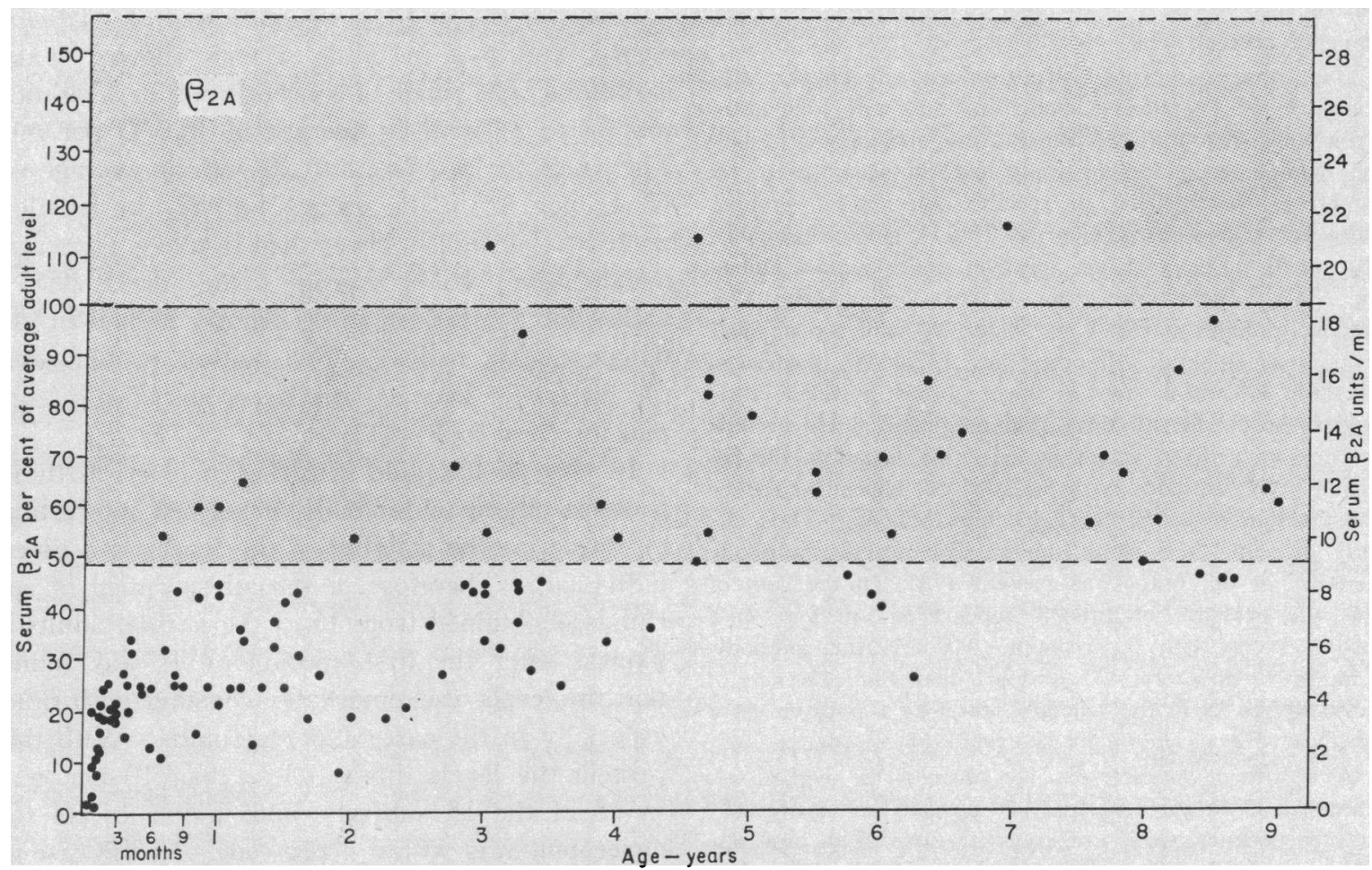

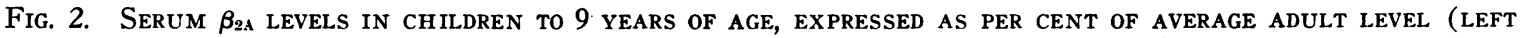
SCALE) AND IN U PER ML (RIGHT SCALE). The shaded area represents the range found in normal adults and the heavy dashed line within the shaded area, the average level for normal adults. 
adult sooner than do the levels of $\beta_{2 \mathrm{~A}}$. The rate of production of $\beta_{2 \mathrm{M}}$ increases within two or three days after birth. In contrast, production of $\beta_{2 \mathrm{~A}}$ does not start until age 25 days. Thus, two of five infants studied on the second and third days of life already had levels of $\beta_{2 \mathrm{M}}$ greater than those in cord serum, but in none of 17 infants studied before the age of 25 days did the $\beta_{2 \mathrm{~A}}$ level exceed that in cord serum. At 3 to 4 months the lowest $\beta_{2 \mathrm{M}}$ levels were within 40 per cent of the average adult level, comparatively higher than the highest $\beta_{2 \Delta}$ level.

The results of $\beta_{2 \mathrm{~A}}$ and $\beta_{2 \mathrm{M}}$ determinations on all infants and children up to the age of 9 years are shown in Figures 2 and 3, respectively. In these graphs the average adult value is shown by a horizontal line and the adult range by the shaded area. It is apparent that the concentration of $\beta_{2 \mathrm{M}}$ reaches the adult range at approximately the age of 9 months. The values remain in this range during the second and third years, but for reasons that are not well understood diminish thereafter. and during the fifth to the ninth years the points lie almost exclusively in the lower portion of the adult range. Levels of $\beta_{2 \mathrm{~A}}$ increase more slowly and show no oscillations. Prior to the age of 4 years, the levels are below the adult range in a high percentage. After the age of 4 years, most values fall within the lower portion of the adult range.

Immunoglobulin levels in hypogammaglobulinemics. In Table I values for $\beta_{2 \mathrm{~A}}, \beta_{2 \mathrm{M}}$, and gamma globulin are shown in 10 patients with agammaglobulinemia or hypogammaglobulinemia ${ }^{1}$ and three with a transient partial immunoglobulin depression. Patients 1 through 6 had typical congenital agammaglobulinemia, and Patient 7 , although a female, may also fall into this category. Patient 8 probably had an acquired agammaglobulinemia. In all these agammaglobulinemics, $\beta_{2 A}$ was less than $0.5 \mathrm{U}$ per $\mathrm{ml}$, but $\beta_{2 \mathrm{M}}$ was often at a perceptible level, one value being as high as 1.75

1 Agammaglobulinemia is arbitrarily defined as a con-
dition in which the gamma globulin concentration is less
than $100 \mathrm{mg}$ per $100 \mathrm{ml}$. In hypogammaglobulinemia the values are above this level but below the normal range.

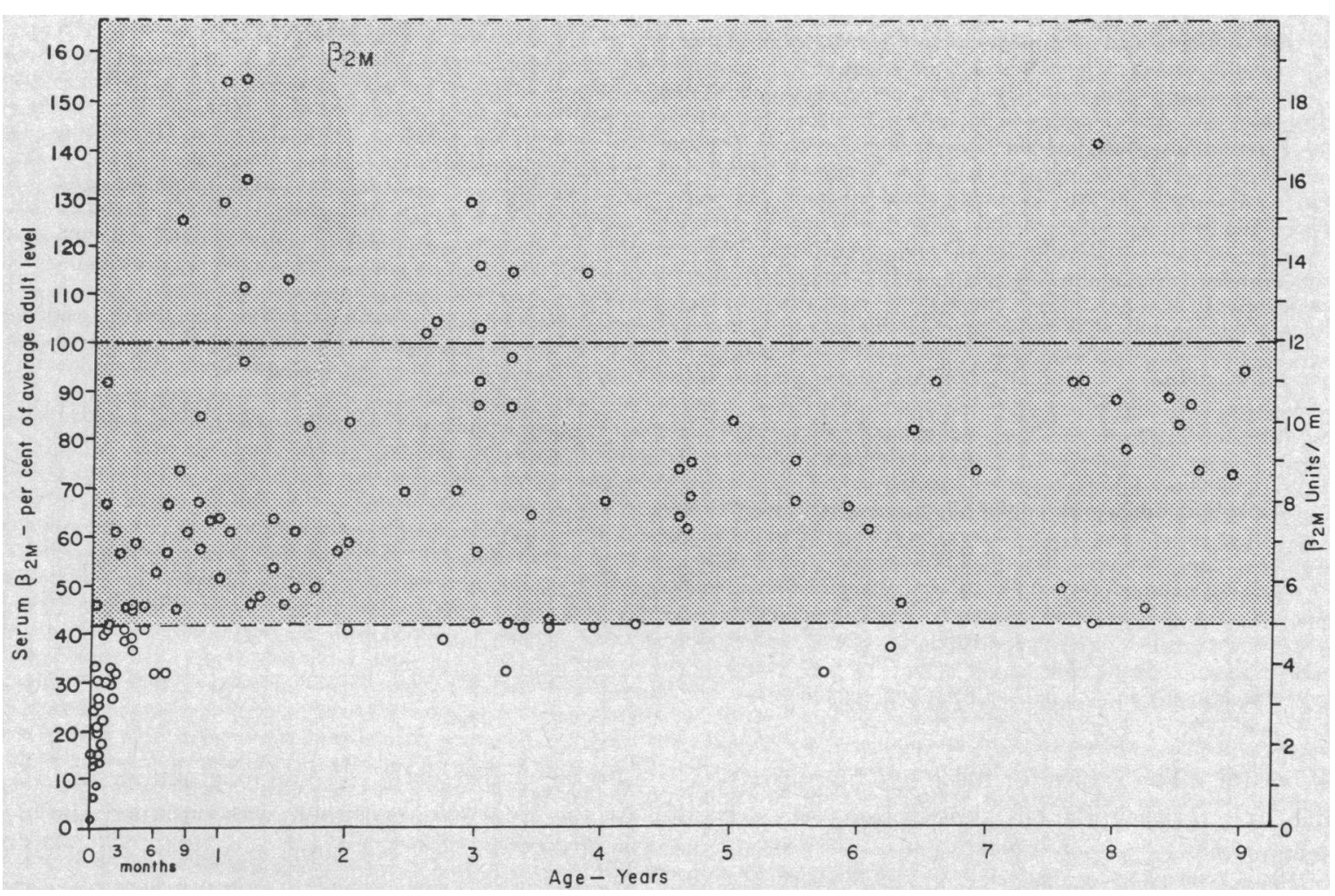

Fig. 3. Serum $\beta_{2 M}$ Levels in ChildRen to 9 years of AGE. 
TABLE I

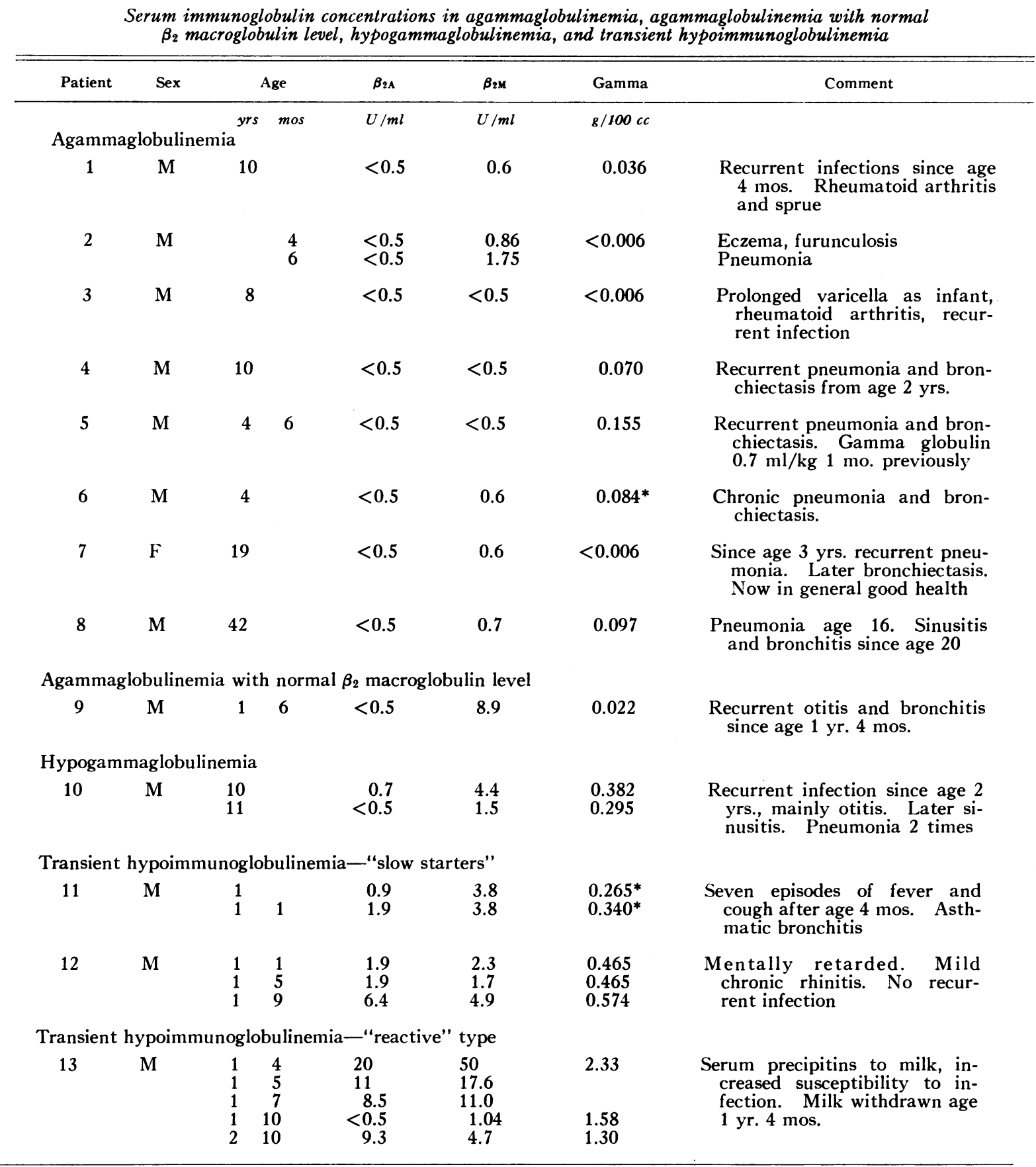

* Determined by paper electrophoresis.

$\mathrm{U}$ per $\mathrm{ml}$. The values for these two immunoglobulins are very similar to those observed in cord serum.

Patient 9 is designated an agammaglobulinemic with a $\beta_{2}$ macroglobulinemia. This condition has also been designated dysgammaglobulinemia (5). At the time this specimen was obtained the $\beta_{2 \mathrm{M}}$ level was normal, but later, as will be reported in greater detail in a separate communication (15), the level went to three times the normal adult 
level and there was evidence that the boy could make small quantities of gamma globulin.

Patient 10, the hypogammaglobulinemic, had, when first studied, a perceptible level of $\beta_{2 \mathrm{~A}}$ and a low normal $\beta_{2 \mathrm{MI}}$. Although his gamma globulin level was not markedly depressed, he had had recurrent infections since the age of 2 years-otitis, chronic sinusitis, and recurrent pneumonia. $\mathrm{He}$ had never received gamma globulin. A male sibling had a similar history, but died at the age of 5 years of meningococcic meningitis. Six other siblings, three of whom are males, have had no difficulty with recurrent infection.

Transient partial hypoimmunoglobulinemia. Two types of conditions were seen in which there was reduction of $\beta_{2 \mathrm{~A}}$ and $\beta_{2 \mathrm{M}}$ globulin concentrations with relatively little abnormality in gamma globulin level. In both, the low levels were transient. Patients 11 and 12 (Table I) are examples of the "slow starter" type, a counterpart of the transient hypogammaglobulinemia of infancy described by others $(16,17)$. Patient 11 , at the age of 12 months, had all the immunoglobulins at the lower limit of the normal range. In his first year, he had had frequent upper and lower respiratory infections and fevers of undetermined origin. At the age of 13 months levels of $\beta_{2 \mathrm{~A}}$ and gamma globulin had increased, and from this time on the child had no further difficulty. Patient 12 , mentally retarded but without recurrent infection, had normal levels of $\beta_{2 \mathrm{~A}}$ and gamma globulin but depressed levels of $\beta_{2 \mathrm{M}}$ at ages 13 months and 17 months. At age 21 months the levels of all the immunoglobulins had increased, and $\beta_{2 \mathrm{M}}$ came into the normal range.

A "reactive" type of transient hypoimmunoglobulinemia was seen in Patient 13, a Negro boy with a high level of precipitins to milk protein $(18,19)$, demonstrable in his serum at age 16 months by the micro-Ouchterlony technique. The many bizarre signs and symptoms he presented have been described in detail previously (19, Case 1 ). While he was on a milk diet at age 16 months. a marked stimulation of the immune system was present as manifested by the high immunoglobulin levels. On substitution of a soybean preparation for milk, there was rapid improvement and the immunoglobulin levels progressively fell, first to normal, and six months later to subnormal, in the case of $\beta_{2 \mathrm{~A}}$ and $\beta_{2 \mathrm{M}}$. No clinical manifesta- tions accompanied this immunoglobulin depression. One year later the levels returned to the normal range.

A similar "reactive" type of immunoglobulin depression was observed in another child with precipitins to milk. After milk was discontinued, the levels of $\beta_{2 \mathrm{~A}}$ and $\beta_{2 \mathrm{M}}$ fell from approximately $50 \mathrm{U}$ per $\mathrm{ml}$ each to 7 for $\beta_{2 \mathrm{~A}}$ and 2.2 for $\beta_{2 \mathrm{M}}$ over a fourteen-month period.

Beta-2A deficiency as an isolated defect. In Table II data on thirteen children with low serum levels of $\beta_{2 \mathrm{~A}}$ and normal or elevated levels of $\beta_{2 \mathrm{M}}$ and gamma globulin are listed. In eight the $\beta_{2 A}$ level was less than $0.5 \mathrm{U}$ per $\mathrm{ml}$; the highest level was $1.7 \mathrm{U}$ per ml. Considerable effort was expended to find distinctive symptoms or signs which might bear a cause or effect relationship to the $\beta_{2 \mathrm{~A}}$ deficiency in these patients. The effort was unsuccessful in that no common denominator could be found. The disorders appearing most frequently were 1) central nervous system damage (Patients 14-18), 2) malabsorption syndrome (Patients 19 and 20), and 3) recurrent minor infections and fevers of unknown origin (Patients 21-25), but these were never so severe as in agammaglobulinemics. Patient 26 had a disease resembling disseminated lupus erythematosus, but a definite diagnosis could not be made. Five of the patients had manifestations of allergy (Patients $12,17,21,22$, and 25). At least two of these had positive skin reactions to various allergens.

Levels of $\beta_{2 \mathrm{M}}$ were elevated only in Patient 18, probably as a result of his liver disease. The elevation of gamma globulin in this patient could also be attributed to liver disease and that in Patient 26 to renal disease. The high levels of gamma globulin seen in Patients 14 and 15 could not be accounted for.

The low levels of $\beta_{2 \mathrm{~A}}$ globulin appeared to be permanent. Four patients, 15, 20, 24, and 26. could be followed for periods ranging from four to seventeen months, and in all the $\beta_{2 \mathrm{~A}}$ level remained less than $0.5 \mathrm{U}$ over the periods of observation.

Aldrich's syndrome. Two patients with Aldrich's syndrome were observed in the course of this study. Both had the typical multiplicity of symptoms and signs-thrombocytopenia, eczematoid dermatitis, otitis media, and increased susceptibility to infection. In both, the serum isoag- 
TABLE II

Serum immunoglobulin levels in isolated $\beta_{2 A}$ deficiency and in Aldrich's syndrome

\begin{tabular}{|c|c|c|c|c|c|c|c|}
\hline Patient & Sex & \multicolumn{2}{|c|}{ Age } & \multirow{2}{*}{$\begin{array}{c}\beta_{2 A} \\
U / m l\end{array}$} & \multirow{2}{*}{$\frac{\beta_{2 \mathrm{M}}}{U / m l}$} & \multirow{2}{*}{$\begin{array}{l}\text { Gamma } \\
g / 100 c c\end{array}$} & \multirow[t]{2}{*}{ Comment } \\
\hline & dof & yrs & mos & & & & \\
\hline 14 & $\mathbf{M}$ & 2 & 2 & 0.7 & 11.6 & 2.75 & $\begin{array}{l}\text { Myoclonic epilepsy. Later grand } \\
\text { mal. Congenital deafness. Re- } \\
\text { tarded }\end{array}$ \\
\hline 15 & $\mathrm{~F}$ & 2 & 4 & $<0.5$ & 13.3 & 2.10 & $\begin{array}{l}\text { Maternal rubella. Congenital deaf- } \\
\text { ness. Congenital heart disease. } \\
\text { Retarded growth. Allergy to } \\
\text { sulfa }\end{array}$ \\
\hline 16 & $\mathrm{~F}$ & 3 & 10 & 0.7 & 8.0 & 0.75 & Petit mal. Mental retardation \\
\hline 17 & M & 4 & 8 & 1.9 & 5.9 & & $\begin{array}{l}\text { Grand mal and akinetic seizures, } \\
\text { onset age } 4 \text { yrs. Hypersensitiv- } \\
\text { ity to Tridione (trimethadione) }\end{array}$ \\
\hline 18 & $\mathbf{M}$ & 15 & & $<0.5$ & 28.6 & 2.10 & $\begin{array}{l}\text { Mental retardation. Cirrhosis and } \\
\text { splenomegaly. Etiology not } \\
\text { known }\end{array}$ \\
\hline 19 & $\mathrm{~F}$ & 1 & 6 & 1.2 & 6.4 & 0.48 & Malabsorption syndrome \\
\hline 20 & $\mathrm{~F}$ & 2 & 11 & $<0.5$ & 6.9 & 0.81 & Malabsorption syndrome \\
\hline 21 & M & 6 & 4 & $<0.5$ & 8.4 & 1.7 & $\begin{array}{l}\text { Recurrent respiratory infection. } \\
\text { Allergic to many drugs and foods }\end{array}$ \\
\hline 22 & $\mathrm{~F}$ & 8 & 7 & $<0.5$ & 9.8 & 1.4 & $\begin{array}{l}\text { Well until age } 6 \text { yrs. Then recur- } \\
\text { rent febrile episodes with cough. } \\
\text { Questionable allergy to molds }\end{array}$ \\
\hline 23 & $\mathbf{M}$ & 3 & 9 & 0.5 & & 0.97 & $\begin{array}{l}\text { Recurrent tonsillitis since age } 1 \mathrm{yr} \text {. } \\
6 \text { mos. }\end{array}$ \\
\hline 24 & $\mathbf{F}$ & 2 & 2 & $<0.5$ & 8.3 & 1.60 & $\begin{array}{l}\text { Recurrent otitis and fevers of un- } \\
\text { known origin since infancy }\end{array}$ \\
\hline 25 & $\mathbf{M}$ & 5 & 11 & $<0.5$ & 6.8 & 0.90 & $\begin{array}{l}\text { Frequent tonsillitis and otitis. Al- } \\
\text { lergic to penicillin, milk, and eggs }\end{array}$ \\
\hline 26 & M & 14 & & $<0.5$ & 5.9 & 1.86 & $\begin{array}{l}\text { Chronic nephritis, cause unknown. } \\
\text { Blood urea nitrogen, } 25 \mathrm{mg} / 100 \\
\text { cc. }\end{array}$ \\
\hline \multicolumn{8}{|c|}{ Aldrich syndrome } \\
\hline 27 & $\mathbf{M}$ & $\begin{array}{l}1 \\
2\end{array}$ & $\begin{array}{l}4 \\
4\end{array}$ & $\begin{array}{l}43 \\
84\end{array}$ & $\begin{array}{c}13 \\
9.3\end{array}$ & $\begin{array}{l}0.93 \\
0.77\end{array}$ & $\begin{array}{l}\text { Eczema, moderate } \\
\text { Eczema, severe. Kaposi's vari- } \\
\text { celliform eruption. Anti-B titer } \\
-\mathrm{O}\end{array}$ \\
\hline 28 & $\mathbf{M}$ & 4 & & 92 & 4.0 & 1.62 & $\begin{array}{r}\text { Eczema, minimal. Anti-B titer } \\
\text { - } 1: 2\end{array}$ \\
\hline
\end{tabular}

glutinins were either in very low titer or absent (20). Results of immunoglobulin determinations are shown in Table II. Striking elevation of the $\beta_{2 \mathrm{~A}}$ globulin level is seen in both patients with normal levels of $\beta_{2 \mathrm{M}}$ and gamma globulin.

\section{DISCUSSION}

If we assume that the rates of disappearance of $\beta_{2 \mathrm{~A}}$ and $\beta_{2 \mathrm{M}}$ do not change with increasing age, the serum levels of these proteins provide indices of their rates of synthesis. In the fetus small quantities of $\beta_{2 M}$ are often present, as judged from the results of cord blood determinations. That this originates in the fetus seems plausible from the large size of the molecule and the rapidity with which its synthesis starts postnatally, although transplacental passage cannot be excluded. On the second to fourth days of life the rate of syn- 
thesis of $\beta_{2 \mathrm{M}}$ increases, and continues at such a rate that adult levels can be attained at age 9 months. Adult levels are maintained on the average for about two years, then drop to about 70 per cent of the adult level during the fifth to ninth years. The reason for this peak with subsequent fall will have to await further studies.

Beta-2A globulin is not made in the fetus, does not pass the placenta, and synthesis does not start until the third or fourth week of life. The rate of synthesis increases slowly and uninterruptedly so that, as with $\beta_{2 \mathrm{M}}$, adult levels are probably achieved during adolescence. In comparison, gamma globulin passes through the placenta and synthesis of it in the infant does not start until the fourth to sixth week (21), a little after the first appearance of $\beta_{2 \mathrm{~A}}$. Adult levels of gamma globulin are achieved about the third year of life. These interrelationships of immunoglobulin synthesis are schematically shown in Figure 4.

The early synthesis of $\beta_{2 \mathrm{M}}$ globulin and the late synthesis of gamma globulin would be expected from observations on antibody formation in newborn infants. Smith (22) and later Fink, LoSpalluto, Miller, and Dorward (23) demonstrated that premature and full-term infants injected with typhoid vaccine develop first an antibody which is a 19S gamma globulin or $\beta_{2 \mathrm{M}}$. This was true of the response to typhoid $\mathrm{H}$, paratyphoid $\mathrm{A}$ and $\mathrm{B}$, as well as typhoid $\mathrm{O}$ antigens. As the infants' titers reached a peak and fell, the type of antibody changed from $19 \mathrm{~S}$ to $7 \mathrm{~S}$.
The serum levels of $\beta_{2 \mathrm{~A}}$ and $\beta_{2 \mathrm{M}}$ globulins, as measured in the present study, agree in a general way with those observed by other workers. Both Franklin and Kunkel (14) and Vivell and Sick (24) demonstrated small amounts of $\beta_{2 \mathrm{M}}$ to be present in most cord serum. Serum levels of both $\beta_{2 \mathrm{~A}}$ and $\beta_{2 \mathrm{M}}$ were studied in the first year of life by Hitzig (25) and Scheidegger and Martin DuPan (26), as well as Vivell and Sick (24). The estimates of concentration made by these authors from the immunoelectrophoretic patterns did not distinguish the different rates at which these two proteins reach adult levels as delineated by the present study.

The patterns of immunoglobulin levels in various immunoglobulin deficiency states suggest that in certain of these disorders there has been an arrest of maturation of the synthetic mechanisms for these proteins. In a number of the congenital agammaglobulinemics (Table I), ability to synthesize immunoglobulins was comparable to that of the fetus in that gamma and $\beta_{2 \mathrm{~A}}$ globulins were either not produced at all or produced in very low quantity, whereas perceptible synthesis of $\beta_{2 \mathrm{M}}$ often did occur. Thus, the congenital agammaglobulinemic might be said to be in the fetal state as far as production of immunoglobulins is concerned. The concept of maturation arrest might be carried a little farther to compare production in agammaglobulinemics who have normal or elevated levels of $\beta_{2 \mathrm{M}}$ (Patient 9, Table I) with immunoglobulin synthesis in the one- to four-week-

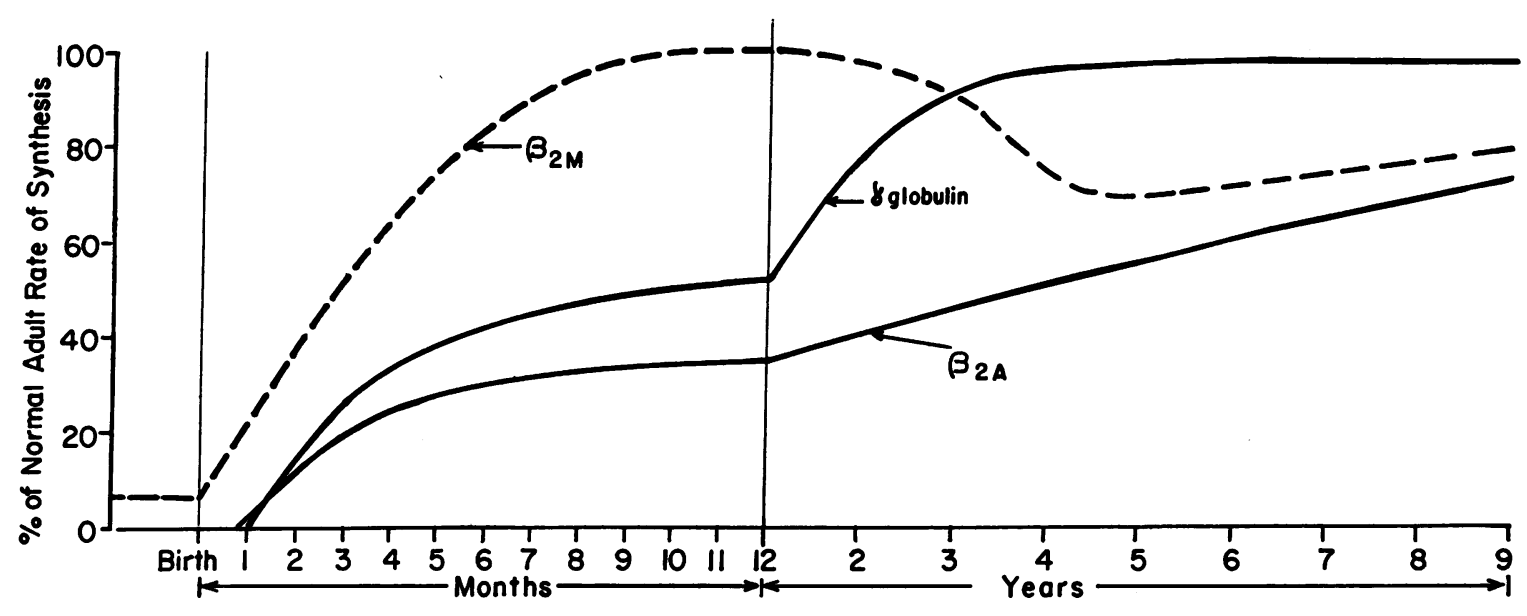

Fig. 4. Schematic Representation of RATES of $\beta_{2 A}, \beta_{2 \mathrm{M}}$, AND GAMMA GLOBUlin Synthesis FROM BIRTH TO AGE 9 YEARS. 
TABLE III

Immunoglobulin patterns in immunoglobulin deficiency states

\begin{tabular}{|c|c|c|c|c|}
\hline & Patient & $\beta_{2 A}$ & $\beta_{2 M}$ & Gamma \\
\hline $\begin{array}{l}\text { Agammaglobulinemia } \\
\text { Agammaglobulinemia with } \beta_{2} \text { macroglobulinemia } \\
\text { Hypogammaglobulinemia } \\
\text { Isolated } \beta_{2 A} \text { deficiency } \\
\text { Transient hypoimmunoglobulinemia, "reactive" type } \\
\text { Transient hypoimmunoglobulinemia, "slow starters" } \\
\text { Giedion and Scheidegger defect }(3,4)\end{array}$ & $\begin{array}{c}1-8 \\
9 \\
10 \\
14-26 \\
13 \\
11-12\end{array}$ & $\begin{array}{l}\downarrow \downarrow \downarrow \\
\downarrow \downarrow \downarrow \\
\downarrow \downarrow \\
\downarrow \downarrow \\
\downarrow \downarrow \\
\downarrow \\
\downarrow \downarrow\end{array}$ & $\begin{array}{l}\downarrow \downarrow \downarrow \\
N \text { or } \uparrow \\
\downarrow \\
N \\
\downarrow \downarrow \\
\downarrow \text { or } \downarrow \downarrow \\
\downarrow \downarrow\end{array}$ & $\begin{array}{c}\downarrow \downarrow \downarrow \\
\downarrow \downarrow \\
\downarrow \\
N \\
N \\
\downarrow \text { or } N \\
N\end{array}$ \\
\hline
\end{tabular}

old infant. Between these ages, $\beta_{2 \mathrm{MI}}$ is produced, but not $\beta_{2 \mathrm{~A}}$ or gamma globulin. It is not valid to consider all patients with this pattern of immunoglobulins as maturation arrests, however, in that the ability to produce macroglobulins is often a transient event in the agammaglobulinemic individual (5).

The hypogammaglobulinemic individual described in the present paper (Patient 10, Table I) could also be considered to represent an arrest of maturation occurring at the one- or two-month level. At this age small amounts of $\beta_{2 \mathrm{~A}}$ and gamma globulin are produced and somewhat greater amounts of $\beta_{2 \mathrm{M}}$, corresponding approximately to the immunoglobulin pattern in this patient. There is no counterpart in the maturation sequence, however, for the individual with low levels of $\beta_{2 \mathrm{~A}}$ as an isolated defect, nor for the patient with Aldrich syndrome with very high levels of $\beta_{2 \mathrm{~A}}$.

Two transient types of partial hypoimmunoglobulinemia are described, the "slow starters" and the "reactive" types. Neither of the two "slow starters" included in the present paper had clinical courses comparable to those of transient hypogammaglobulinemics, nor were comparably low gamma globulin levels observed $(16,17)$. In Patient 11 (Table I), all the immunoglobulins were transiently at the low limit of normal, and symptoms were suggestive of inability to produce antibody. With the spontaneous increase in immunoglobulin levels, the symptoms disappeared. Patient 12 (Table I), was most defective in $\beta_{2 \mathrm{M}}$ synthesis, less so in $\beta_{2 \mathrm{~A}}$ and gamma synthesis. Of many serum specimens studied by immunoelectrophoretic analysis, those from this child were the closest to demonstrating an isolated $\beta_{2 \mathrm{M}}$ deficiency. It is interesting that no symptoms accompanied this de- ficiency. These observations indicate that the immunoglobulins, collectively or singly, can exhibit delayed maturation.

Transient hypoimmunoglobulinemia of the "reactive" type has not been described. It can be thought of as an example of overcompensation on withdrawal of immune stimulation and is interesting in that it does not involve gamma globulin. If the serum levels of the immunoglobulins control to any extent the rates of their synthesis, the present observation would indicate that this feedback mechanism operates sluggishly in the case of $\beta_{2 A}$ and $\beta_{2 M}$.

The very high level of $\beta_{2 A}$ in Aldrich's syndrome is also a unique observation. These high levels would appear to be basic to the disease rather than the result of a complication. Chronic infection does tend to increase serum levels of $\beta_{2 A}$, but the infections are usually of a severe and long-standing type such as histoplasmosis, subacute bacterial endocarditis, and chronic osteomyelitis. In these conditions increased levels of $\beta_{2 \times I}$ and gamma globulin are often observed as well. and levels of $\beta_{2 A}$ do not approach those seen in Aldrich's syndrome. In the children with Aldrich's syndrome, the only chronic infection present was infected eczema and otitis media. In $\mathrm{Pa}-$ tient 28 (Table II), who had the highest $\beta_{2 \mathrm{~A}}$ level. there was no otitis demonstrable and the eczema was minimal at the time the blood was obtained. The basis for the marked elevation of $\beta_{2 \mathrm{~A}}$ globulin is, therefore, unexplained. It is perhaps correlated with the generalized, nonspecific hyperplasia of lymph nodes found in this disease (20). It is interesting that levels of $\beta_{2 \mathrm{~A}}$ in histiocytosis, a disease which clinically has many manifestations similar to those of Aldrich's syndrome, have been found to be normal (12). 
In comparing characteristics of the immunoglobulin patterns in the various antibody and immunoglobulin deficiency states, as shown in Table III, it becomes apparent that, except in Aldrich's syndrome, a common characteristic is a reduction in $\beta_{2 \mathrm{~A}}$ globulin. Thus, the $\beta_{2 \mathrm{~A}}$ level was below the normal range in all patients with a- or hypogammaglobulinemia, and it was in the low normal range or below in the patients with transient hypoimmunoglobulinemia. In patients with the Giedion and Scheidegger defect $(3,4)$ one of the abnormalities in the immunoelectrophoretic pattern is absence of $\beta_{2 \mathrm{~A}}$ globulin. Thus it would appear to be a rule that $\beta_{2 \mathrm{~A}}$ levels will be depressed in patients with depressed levels of $\beta_{2 M}$ or gamma globulin. The single exception to this rule is a patient mentioned by Heremans (27) who had a gamma globulin synthesizing defect but had normal levels of $\beta_{2 \mathrm{~A}}$ and $\beta_{2 \mathrm{MI}}$.

Although such a rule may have fairly general application, its converse, that a low $\beta_{2 \mathrm{~A}}$ level is always accompanied by a defect in synthesis of one or both of the other two immunoglobulins, is obviously not correct. Patients 14 to 26 had an isolated $\beta_{2 A}$ deficiency, but had no other immunoglobulin abnormality and had no symptoms or signs suggestive of an antibody deficiency state. Two of these patients with less than $0.5 \mathrm{U}$ of $\beta_{2 \mathrm{~A}}$ were highly allergic and had positive skin tests, a circumstance which must be reconciled with recent observations linking $\beta_{2 \mathrm{~A}}$ with reaginic activity (2). The fact that all of the individuals with low $\beta_{2 \mathrm{~A}}$ had disease may be a function of the fact that they were found in the course of examining the immunoelectrophoretic patterns of a number of hospital patients. It is possible that screening an equal number of normal subjects would result in a similar incidence of $\beta_{2 \mathrm{~A}}$ deficiency.

\section{SUM MARY}

Determination of the serum levels of $\beta_{2 \mathrm{~A}}$ and $\beta_{2 M}$ globulins in infants, children, and adults indicates that the synthetic mechanisms for these immunoglobulins develop and mature at different times. Beta-2 macroglobulin synthesis may occur at a slow rate in the fetus. Within two to three days after birth, the rate of synthesis increases rapidly so that adult serum levels may be achieved at age 9 months. Levels are maintained in the adult range for about two years thereafter and then fall to an average value which is 70 per cent of the adult mean. Beta-2A globulin is probably absent from the serum of the fetus, and synthesis of it does not start until the fourth week of life. The rate of synthesis increases slowly and steadily so that, as with $\beta_{2 \mathrm{M}}$, the average adult serum level is probably finally achieved at puberty.

In normal adults, serum levels of $\beta_{2 \mathbf{A}}$ vary over a wide range, but in a given individual they are remarkably constant. Levels of $\beta_{2 \mathrm{M}}$ also show a wide range but are less constant.

The pattern of immunoglobulin production in the agammaglobulinemic is comparable to that in the fetus. A child with agammaglobulinemia but with normal levels of $\beta_{2 \mathrm{M}}$ and a hypogammaglobulinemic child (serum gamma levels above $100 \mathrm{mg}$ per cent) appeared to have immunoglobulin synthetic mechanisms comparable to those of a one-week-old and a four- or five-week-old infant, respectively.

Beta-2A deficiency as an isolated defect was observed in 13 children. Although all had disease, there were no consistent signs or symptoms that could be causally related to or could have been produced by the $\beta_{2 \mathrm{~A}}$ deficiency. There was no consistent, clinical evidence of antibody deficiency.

A transient hypoimmunoglobulinemia occurring in the infant as a result of slow maturation of synthetic mechanisms can involve one or several immunoglobulins. A transient hypoimmunoglobulinemia can also occur after sudden withdrawal of a long-sustained stimulus to the immune system.

Beta-2A globulin is more frequently deficient than either of the other two immunoglobulins. In the present series it was absent or in low concentration in all conditions in which gamma or $\beta_{2 \mathrm{M}}$ were low. As a general rule, it can be said that a $\beta_{2 \mathrm{~A}}$ synthesizing defect always accompanies a defect in gamma or $\beta_{2 M}$ synthesis. In addition, $\beta_{2 A}$ deficiency is frequently seen as an isolated defect. Deficiency of $\beta_{2 M}$ as an isolated abnormality is rare.

Unexplainable marked elevations of the serum levels of $\beta_{2 A}$ were found in two patients with Aldrich's syndrome. In these patients the serum levels of $\beta_{2 M}$ and gamma globulin were normal.

\section{REFERENCES}

1. Heremans, J. F., Heremans, M. T.-Th., and Schultze, H. E. Isolation and description of a few properties of the $\beta_{2 A}$-globulin of human serum. Clin. chim. Acta 1959, 4, 96. 
2. Heremans, J. F., and Vaerman, J. P. $\beta_{2 \Delta}$-globulin as a possible carrier of allergic reaginic activity. Nature (Lond.) 1962, 193, 1091.

3. Giedion, von A., and Scheidegger, J. J. Kongenitale Immunparese bei Fehlen spezifischer $\beta_{2}$-Globuline und quantitativ normalen $\boldsymbol{\gamma}$-Globulinen. Helv. paediat. Acta 1957, 12, 241.

4. Barandun, S., Huser, H. J., and Hässig, A. Klinische Erscheinungsformen des Antikörpermangelsyndroms. Schweiz. med. Wschr. 1958, 88, 78.

5. Rosen, F. S., Kevy, S. V., Merler, E., Janeway, C. A., and Gitlin, D. Recurrent bacterial infections and dysgammaglobulinemia: deficiency of 7S gammaglobulins in the presence of elevated 19S gammaglobulins. Report of two cases. Pediatrics 1961, 28, 182.

6. Israel-Asselain, R., Burtin, P., and Chebat, J. Un trouble biologique nouveau, l'agammaglobulinémie avec $\beta 2$ macroglobulinémie. Bull. Soc. méd. Hôp. Paris 1960, 76, 519.

7. West, C. D., Hinrichs, V., and Hinkle, N. H. Quantitative determination of the serum globulins beta $2 \mathrm{~A}$ and beta $2 \mathrm{M}$ by immunoelectrophoretic analysis. $\mathrm{J}$. Lab. clin. Med. 1961, 58, 137.

8. Aldrich, R. A., Steinberg, A. G., and Campbell, D. C. Pedigree demonstrating a sex-linked recessive condition characterized by draining ears, eczematoid dermatitis and bloody diarrhea. Pediatrics 1954, 13, 133.

9. Franklin, E. C., and Kunkel, H. G. Immunologic differences between the $19 \mathrm{~S}$ and $7 \mathrm{~S}$ components of normal human $\gamma$-globulin. J. Immunol. 1957, $78,11$.

10. Franklin, E. C. Immunologic differences between the $7 \mathrm{~S}$ and $19 \mathrm{~S}$ components of normal human $\gamma$-globulin; antigenic specificity of the 7S component. J. Immunol. 1960, 85, 138.

11. Franklin, E. C., and Stanworth, D. R. Studies on the antigenic specificity of human $7 \mathrm{~S}$ gamma globulin. Fed. Proc. 1961, 20, 31.

12. West, C. D., and Hong, R. Unpublished studies.

13. Hong, R., and West, C. D. Immunoelectrophoretic technique for gamma globulin quantitation. To be published.

14. Franklin, E. C., and Kunkel, H. G. Comparative levels of high molecular weight (19S) gamma globulin in maternal and umbilical cord sera. J. Lab. clin. Med. 1958, 52, 724.

15. Hong, R., Schubert, W. K., and West, C. D. Anti- body deficiency syndrome associated with beta-2 macroglobulinemia. J. Pediat. In press.

16. Gitlin, D., Gross, P. A. M., and Janeway, C. A. The gamma globulins and their clinical significance. (continued) II. Hypogammaglobulinemia. New Eng. J. Med. 1959, 260, 72.

17. Good, R. A., Zak, S. J., Condie, R. M., and Bridges, R. A. Clinical investigation of patients with agammaglobulinemia and hypogammaglobulinemia. $\mathrm{Pe}$ diat. Clin. N. Amer. 1960, 7, 397.

18. Heiner, D. C., Sears, J. W., and Kniker, W. T. Multiple precipitins to cow's milk in chronic respiratory disease. Amer. J. Dis. Child. 1962, 103, 634.

19. Hinkle, N. H., Hong, R., Davis, N. C., and West, C. D. Significance of precipitating antibodies to milk protein in the serum of infants and children. J. Pediat. 1962, 61, 181.

20. Krivit, W., and Good, R. A. Aldrich's syndrome (thrombocytopenia, eczema, and infection in infants). Amer. J. Dis. Child. 1959, 97, 137.

21. Zak, S. J., and Good, R. A. Immunochemical studies of human serum gamma globulins. J. clin. Invest. 1959, 38, 579.

22. Smith, R. T. Response to active immunization of human infants during the neonatal period in Ciba Foundation Symposium on Cellular Aspects of Immunity, G. E. W. Wolstenholme and M. O'Connor, Eds. Boston, Little, Brown, 1960, pp 348-368.

23. Fink, C. W., LoSpalluto, J., Miller, W., Jr., and Dorward, B. The sequences of gamma globulin formation in immunized premature infants : macroglobulin (19S) antibody formation followed by 7S antibody (abstract). Amer. J. Dis. Child. 1961, $102,460$.

24. Vivell, O., and Sick, T. Immunelektrophoretische Untersuchungen über die Entwicklung der Serumproteine beim Menschen. Z. Kinderheilk. 1960, 84, 349.

25. Hitzig, W. H. Die physiologische Entwicklung der «Immunglobuline» (Gamma-und Beta-2-Globuline). Helv. paediat. Acta 1957, 12, 596.

26. Scheidegger, J. J., and Martin DuPan, R. Etude immuno-électro-phorétique des protéines seriques du nouveau-né et du nourrisson. Etud. néo-natal. 1957, 6, 135.

27. Heremans, J. F. Immunochemical studies on protein pathology. The immunoglobulin concept. Clin. chim. Acta 1959, 4, 639. 